\title{
Functional properties of factor Va subunits after proteolytic alterations by activated protein $\mathrm{C}$
}

Citation for published version (APA):

van de Waart, P., Bruls, H., Hemker, H. C., \& Lindhout, T. (1984). Functional properties of factor Va subunits after proteolytic alterations by activated protein C. Biochimica et Biophysica Acta-general Subjects, 799(1), 38-44. https://doi.org/10.1016/0304-4165(84)90324-6

Document status and date:

Published: 25/05/1984

DOI:

10.1016/0304-4165(84)90324-6

Document Version:

Publisher's PDF, also known as Version of record

\section{Please check the document version of this publication:}

- A submitted manuscript is the version of the article upon submission and before peer-review. There can be important differences between the submitted version and the official published version of record.

People interested in the research are advised to contact the author for the final version of the publication, or visit the DOI to the publisher's website.

- The final author version and the galley proof are versions of the publication after peer review.

- The final published version features the final layout of the paper including the volume, issue and page numbers.

Link to publication

\footnotetext{
General rights rights.

- You may freely distribute the URL identifying the publication in the public portal. please follow below link for the End User Agreement:

www.umlib.nl/taverne-license

Take down policy

If you believe that this document breaches copyright please contact us at:

repository@maastrichtuniversity.nl

providing details and we will investigate your claim.
}

Copyright and moral rights for the publications made accessible in the public portal are retained by the authors and/or other copyright owners and it is a condition of accessing publications that users recognise and abide by the legal requirements associated with these

- Users may download and print one copy of any publication from the public portal for the purpose of private study or research.

- You may not further distribute the material or use it for any profit-making activity or commercial gain

If the publication is distributed under the terms of Article $25 \mathrm{fa}$ of the Dutch Copyright Act, indicated by the "Taverne" license above, 
BBA 21709

\title{
FUNCTIONAL PROPERTIES OF FACTOR Va SUBUNITS AFTER PROTEOLYTIC ALTERATIONS BY ACTIVATED PROTEIN C
}

\author{
PIET VAN DE WAART, HARRY BRULS, H. COENRAAD HEMKER and THEO LINDHOUT * \\ Department of Biochemistry, Biomedical Center, Rijksuniversiteit Limburg, P.O. Box 616, 6200 MD Maastricht (The Netherlands)
}

(Received December 23rd, 1983)

Key words: Factor Va; Protein C; Phospholipid-protein interaction; Subunit interaction; (Bovine)

The two-subunit structure of the factor Va molecule is essential to its function in the prothrombinase complex. In the presence of phospholipids, the cleavage of the light chain of bovine factor $\mathrm{Va}$ by activated protein $\mathrm{C}$ proceeded at the same rate as the cleavage of the heavy chain. The limited proteolysis of factor $\mathrm{Va}$ is accompanied by a parallel loss of factor Va activity. Evidence that loss of activity was solely the result of the cleavage of the heavy chain, was obtained from reconstitution experiments utilizing cleaved and intact chains. The pseudo first-order rate constant of factor $\mathrm{Va}$ inactivation by activated protein $\mathrm{C}$ was found to be dependent on the amount of phospholipid-bound activated protein $\mathrm{C}$ and not on the amount of phospholipidbound factor Va. However, phospholipids enhance the rate of proteolysis of the phospholipid-binding subunit, i.e. the light chain, and not the cleavage of the heavy chain. Cleavage of the heavy chain and as a consequence the inactivation of factor $\mathrm{Va}$ by activated protein $\mathrm{C}$ is mediated by phospholipid-bound light chain. After cleavage of the light chain, the 'two-subunit' structure, as well as the phospholipid-binding properties of factor Va were found to be conserved.

\section{Introduction}

Activated protein $\mathrm{C}$, which is derived by limited proteolysis of the zymogen by thrombin, trypsin or factor X-converting protein from Russell's viper venom [1-3], exhibits anticoagulant activity. This anticoagulant effect is the result of the inactivation of factor $\mathrm{Va}$ and factor VIII : $\mathrm{C}$ by activated protein C [3-8].

Current knowledge about the molecular events that lead to the inactivation of factor $\mathrm{Va}$ by activated protein $\mathrm{C}$ has emerged from studies on factor Va degradation, utilizing SDS-polyacrylamide gel electrophoresis $[3,7,8]$. It was inferred that proteolysis of the $94-\mathrm{kDa}$ subunit of factor $\mathrm{Va}$ (factor Va heavy chain) results in the inactivation of factor $\mathrm{Va}$. Whether proteolysis of the $80-\mathrm{kDa}$

\footnotetext{
* To whom correspondence should be addressed.
}

subunit (factor Va light chain)affects the functional properties of factor $\mathrm{Va}$ is not known.

Phospholipids greatly enhance the rate of factor $\mathrm{Va}$ inactivation by activated protein $\mathrm{C}[2,3,8]$. Activated protein $\mathrm{C}$ and factor $\mathrm{Va}$ bind to phospholipid with dissociation constants of approx. $10^{-5} \mathrm{M}$ [9] and $10^{-8} \mathrm{M}$ [10], respectively. However, it is an open question whether both proteins have to bind to phospholipid in order to obtain an efficient inactivation reaction [11]. Therefore, in view of the observations that the factor Va heavy chain is bound to phospholipid by means of factor Va light chain [10] and phospholipids stimulate the cleavage of factor $\mathrm{Va}$ heavy chain if factor $\mathrm{Va}$ light chain is present $[3,8]$, the question has' to be addressed as to the organization of the factor Va molecule on the phospholipid surface, when factor Va and especially factor $\mathrm{Va}$ light chain is processed by activated protein $\mathrm{C}$. 
This study of the structural alterations in the subunits of factor $\mathrm{Va}$ as induced by activated protein $\mathrm{C}$ was undertaken to obtain better insight into the consequences as to the functional properties of factor $\mathrm{Va}$ and the inactivation process of factor Va. A preliminary account of this work has been published [12].

\section{Materials and Methods}

Materials. Russell's viper venom, ovalbumin and dioleoylphosphatidylcholine were from Sigma Chemical Co. The chromogenic substrate D-phenylalanyl-L-pipecolyl-L-arginine-p-nitroanilide dihydrochloride (S2238) was partially donated by AB Kabi Diagnostica.

Protein preparations. Protein C was isolated from bovine plasma by a modification [3] of the method according to Stenflo [11]. Factor X-activator from Russell's viper venom (RVV-X) was purified as described by Schiffman et al [13]. Protein $\mathrm{C}$ was activated with RVV-X and purified as reported by Walker et al [3]. Activated protein $\mathrm{C}$ concentrations were calculated from the absorbance at $280 \mathrm{~nm}$ using $A^{1 \%}=13.7$ [1]. Bovine factor $\mathrm{V}$ and factor $\mathrm{Va}$ were prepared by a modification [14] of the method of Esmon [15]. Factor Va subunits and all other proteins used in this study were purified and quantitated as described previously [10].

Factor Va assay. A sample $(10-100 \mu \mathrm{l})$ containing factor $\mathrm{Va}$ was incubated with factor $\mathrm{Xa}$ (1.3. $\left.10^{-11} \mathrm{M}\right)$, phospholipid $\left(1.0 \cdot 10^{-5} \mathrm{M}\right)$, and $\mathrm{CaCl}_{2}$ $\left(1.0 \cdot 10^{-2} \mathrm{M}\right)$ in $50 \mathrm{mM}$ Tris, $100 \mathrm{mM} \mathrm{NaCl}, 0.5$ $\mathrm{mg}$ ovalbumin $/ \mathrm{ml}$ in a final volume of $0.9 \mathrm{ml}$ for 5 $\min$ at $37^{\circ} \mathrm{C}$ in a plastic cuvette. The reaction was initiated by the addition of $0.1 \mathrm{ml}$ of prothrombin $\left(2.0 \cdot 10^{-6} \mathrm{M}\right)$. After $2 \mathrm{~min}, 1.0 \mathrm{ml}$ buffer containing $50 \mathrm{mM}$ Tris, $100 \mathrm{mM} \mathrm{NaCl}, 0.5 \mathrm{mg}$ of ovalbumin, $20 \mathrm{mM}$ EDTA and $0.47 \mu \mathrm{mol} \mathrm{S} 2238$ was added to the reaction mixture. The amount of thrombin formed was calculated from the absorbance change as monitored with an Aminco DW-2 spectrophotometer operating in the dual wave-length mode $\left(\lambda_{\mathrm{s}}=405 \mathrm{~nm}\right.$ and $\left.\lambda_{\mathrm{r}}=500 \mathrm{~nm}\right)$, at $37^{\circ} \mathrm{C}$. A factor $\mathrm{Va}$ preparation of which the molar concentration was determined as described previously [10], was used for the construction of standard curves.
Iodination of factor $\mathrm{Va}$ subunits. Factor $\mathrm{V}$ was iodinated using Bolton-Hunter reagent [16]. ${ }^{125} \mathrm{I}$ Factor $\mathrm{V}$ was activated with thrombin and the ${ }^{125} \mathrm{I}$-labelled factor $\mathrm{Va}$ subunits were isolated as described previously [17].

Proteolysis of factor Va subunits by activated protein $C$. Factor $\mathrm{Va}$ light chain $(6 \mu \mathrm{M})$ in $20 \mathrm{mM}$ Tris, $50 \mathrm{mM} \mathrm{NaCl}, 3 \mathrm{mM} \mathrm{CaCl}, \mathrm{pH} 7.5$ was incubated with activated protein $\mathrm{C}(100 \mathrm{nM})$ in the presence of $20 \mu \mathrm{M}$ phospholipid for $10 \mathrm{~min}$ at $37^{\circ} \mathrm{C}$. Upon complete conversion of factor $\mathrm{Va}$ light chain, activated protein $\mathrm{C}$ was quantitatively removed from the mixture by chromatography on a SP-Sephadex column $(0.9 \times 10 \mathrm{~cm})$ and washing the column with the above buffer. Factor Va light chain proteolysis products, i.e. fragments with $M_{\mathrm{r}}$ 51000 and $M_{\mathrm{r}} 32000$ were eluted from the column with $20 \mathrm{mM}$ Tris, $200 \mathrm{mM} \mathrm{NaCl}$, pH 7.5.

Factor Va heavy chain $(7 \mu \mathrm{M})$ in $20 \mathrm{mM}$ Tris, $100 \mathrm{mM} \mathrm{NaCl}, 3 \mathrm{mM} \mathrm{CaCl}_{2}, \mathrm{pH} 7.5$ was incubated with activated protein $\mathrm{C}(0.5 \mu \mathrm{M})$ for 90 min at $37^{\circ} \mathrm{C}$. After complete conversion of factor $\mathrm{Va}$ heavy chain, the reaction mixture was applied to a QAE-Sephadex column $(0.9 \times 10 \mathrm{~cm})$ equilibrated in the above buffer omitting $\mathrm{Ca}^{2+}$. The factor $\mathrm{Va}$ heavy chain proteolysis products, i.e. fragments with $M_{\mathrm{r}} 72000$ and $M_{\mathrm{r}} 24000$, were eluted from the column with $20 \mathrm{mM}$ Tris, $350 \mathrm{mM}$ $\mathrm{NaCl}, \mathrm{pH} 7.5$.

Inactivation of factor $\mathrm{Va}$. Factor $\mathrm{Va}(0.1 \mu \mathrm{M})$ in $50 \mathrm{mM}$ Tris, $100 \mathrm{mM} \mathrm{NaCl}, 3 \mathrm{mM} \mathrm{CaCl}$, $\mathrm{pH} 7.5$ was incubated with activated protein $\mathrm{C}(2 \mathrm{nM})$ in the presence of varying amounts of phospholipid. After the reaction was initiated, samples were removed from the reaction mixture and assayed fro factor Va. For each time course the apparent first-order rate constant for the inactivation of factor Va was calculated from the slope of a plot of $\log$ factor $\mathrm{Va}$ activity versus time. The plots were linear until $60 \%$ of the factor Va was inactivated.

HPLC of factor Va subunits. Size-exclusion high-performance liquid chromatography was carried out on Spherogel TSK 3000 SW $(7.5 \times 600$ $\mathrm{mm}$ ) in $20 \mathrm{mM}$ Tris, $700 \mathrm{mM} \mathrm{NaCl}, \mathrm{pH} 7.5$ at a flow rate of $1.0 \mathrm{ml} / \mathrm{min}$. The instrument was a Beckmann Model 500 high-performance liquid chromatograph equipped with a Beckmannn Model 160 Absorbance Detector. A 280-nm filter was 
used to detect the protein peaks. Samples $(100 \mu 1)$ were injected after a 30 -min period of incubation at $37^{\circ} \mathrm{C}$ in the column buffer.

Protein-binding measurements. Binding of protein to phospholipid was measured as previously described [10]. Briefly, mixtures of large-volume vesicles and protein were incubated for $10 \mathrm{~min}$ at room temperature. Prior to and after centrifugation for $30 \mathrm{~min}$ at $30000 \times \mathrm{g}$, aliquots were withdrawn and assayed for protein for determination of total protein concentration and the concentration of unbound protein, respectively.

Phospholipid preparations. Large-volume and sonicated phospholipid vesicles containing $80 \%$ (w/w) dioleoylphosphatidylcholine and 20\% (w/w) dioleoylphosphatidylserine were prepared as described previously [10].

\section{Results}

Degradation of bovine factor Va by activated bovine protein $C$

Thrombin-activated factor $\mathrm{V}$ (unfractionated factor $\mathrm{Va}$ ) consists of four polypeptides, e.g. factor Va light chain $\left(M_{\mathrm{r}} 80000\right)$, factor Va heavy chain ( $M_{\mathrm{r}}$ 94000), a $M_{\mathrm{r}} 160000$ fragment which is very rich in carbohydrate and a $M_{\mathrm{r}} 65000$ fragment. Factor Va light chain is associated via calcium ions with factor $\mathrm{Va}$ heavy chain and together constitute active factor $\mathrm{Va}[14,15]$. Identical activation fragments have been reported for thrombinactivated human factor $\mathrm{V}$ [17].

Unfractionated factor $\mathrm{Va}$ was incubated with activated protein $\mathrm{C}$ in the presence of phospholipids and the decrease in factor $\mathrm{Va}$ activity was compared with proteolytic events as monitored by SDS-polyacrylamide gel electrophoresis (Fig. 1). Factor Va activity decreased in parallel with the degradation of both factor Va heavy chain and factor $\mathrm{Va}$ light chain, giving rise to fragments ranging from $M_{\mathrm{r}} 72000$ to $M_{\mathrm{r}} 24000$.

The $M_{\mathrm{r}} 150000$ and $M_{\mathrm{r}} 65000$ fragments present in the unfractionated factor Va preparation are not visualized by staining with Coomassie Blue. As monitored by SDS-polyacrylamide gel electrophoresis and visualized by staining with periodic acid-Schiff's reagent, we found that these fragments are not degraded by activated protein C (data not shown).

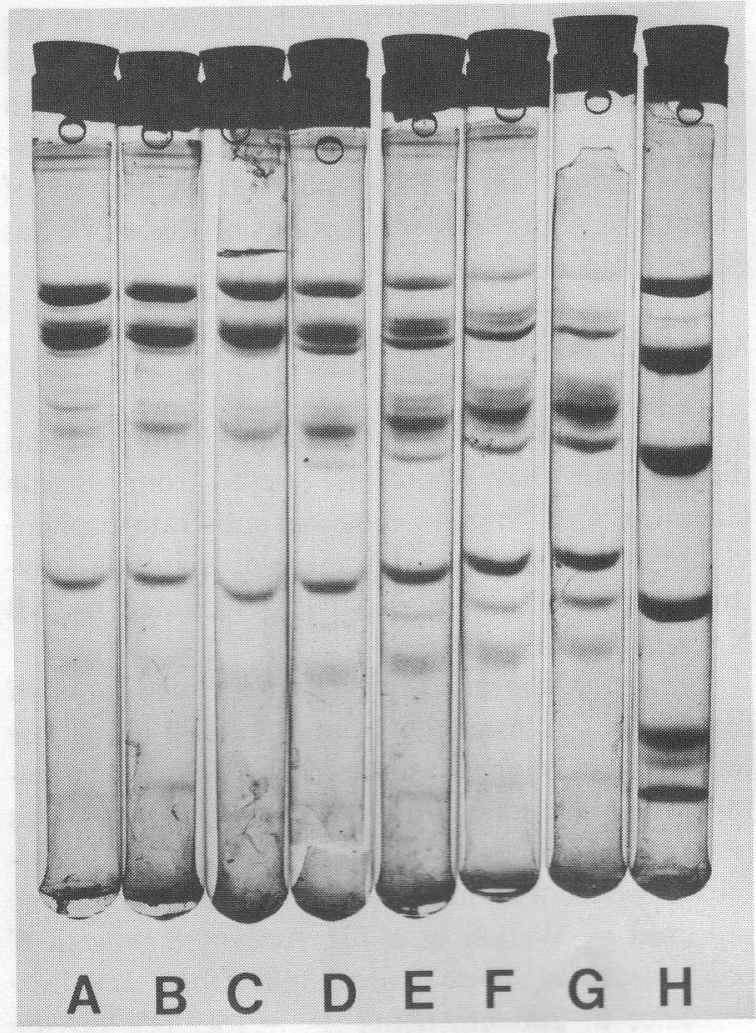

Fig. 1. Degradation of thrombin-activated factor $\mathrm{V}$ by activated protein C. Factor $\mathrm{Va}(1.0 \mu \mathrm{M})$ in $50 \mathrm{mM}$ Tris, $100 \mathrm{mM} \mathrm{NaCl}, 3$ $\mathrm{mM} \mathrm{CaCl} 2, \mathrm{pH} 7.5$, phospholipid $(100 \mu \mathrm{M})$ and activated protein $\mathrm{C}(20 \mathrm{nM})$ were incubated at $37^{\circ} \mathrm{C}$. At intervals, aliquots were removed for factor Va assay and $10 \%$ SDS-polyacrylamide gel electrophoresis. The respective incubation times ( $\mathrm{min})$ and factor $\mathrm{Va}$ activities (\%, in parentheses) were: A, 0 (100); B, 0.5 (95); C, 1 (90); D, 4 (45); E, 8 (24); F, 15 (9); J, 30 (0). Gel H, molecular weight standards (phosphorylase $b, 94000$; bovine serum albumin, 67000; ovalbumin, 43000; carbonic anhydrase, 30000 ; soybean trypsin inhibitor, 20100; $\alpha$ lactalbumin 14400 .

Isolated factor $\mathrm{Va}$ light chain and factor $\mathrm{Va}$ heavy chain were degraded by activated protein C to determine the origin of the degradation products. In accordance with the recently reported degradation pattern of human factor $\mathrm{Va}$ [8], we found that the fragments with $M_{\mathrm{r}} 51000$ and $M_{\mathrm{r}}$ 32000 emerge from the doublet, factor Va light chain $\left(M_{\mathrm{r}} 80000-78000\right)$. Factor Va heavy chain is converted into fragments with $M_{\mathrm{r}} 72000$ and $M_{\mathrm{r}}$ 24000. A further degradation of the $M_{\mathrm{r}} 7200$ fragment gave rise to a $M_{\mathrm{r}} 47000$ and $M_{\mathrm{r}} 30000$ fragment. 
Effect of phospholipids on the rate of proteolysis of factor Va and its subunits

The rate of inactivation of factor $\mathrm{Va}$ by activated protein $\mathrm{C}$ is stimulated by negatively charged phospholipid $[3,7,8]$. However, the kinetics of factor $\mathrm{Va}$ inactivation are poorly understood.

As a first attempt to investigate this problem, we tried to correlate the apparent first-order rate constant of inactivation, $k$, with concentrations phospholipid-bound factor $\mathrm{Va}$ and/or phospholipid-bound activated protein C. Fig. 2 shows the effect of phospholipid concentration on the apparent first-order rate constant. It is demonstrated that the rate constant is proportional with the phospholipid concentration. The amount of phospholipid-bound activated protein $\mathrm{C}$ also increase proportionally with the phospholipid concentration. However, at $30 \mu \mathrm{M}$ phospholipid nearly $100 \%$ of total added factor $\mathrm{Va}$ was bound. The binding experiments were performed at room temperature, while the kinetic studies were carried out at $37^{\circ} \mathrm{C}$. However, the binding of factor $\mathrm{Va}$ did not change significantly in this temperature range. Apparently, under conditions of first-order kinetics, the rate constant, $k$, is independent of the amount of unbound factor $\mathrm{Va}$ and the substrate density at the phospholipid surface, but depends on the amount of phospholipid-bound activated protein

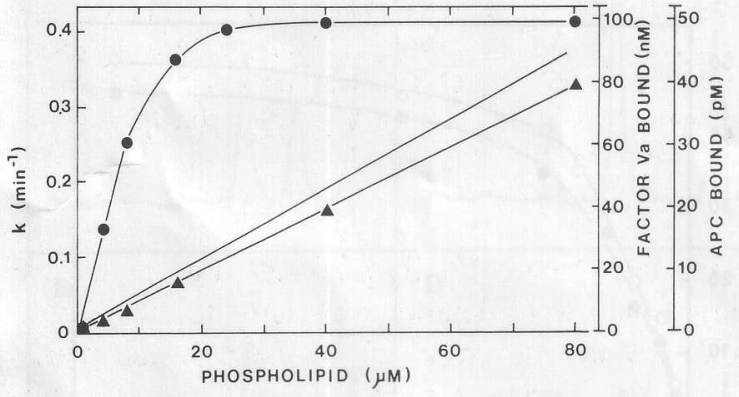

Fig. 2. Effect of phospholipid concentration on the pseudo first-order rate constant of factor $\mathrm{Va}$ inactivation by activated protein C (APC). The reaction was carried out as described in Materials and Methods. The rate constant, $k(\mathbf{\Delta}-\mathbf{\Delta})$, was determined from the slope of a plot of log factor Va concentration versus time. The concentration of phospholipid-bound factor $\mathrm{Va}(-$ ) was determined from identical reaction mixtures but omitting activated protein $\mathrm{C}$. The concentrations of phospholipid-bound activated protein $\mathrm{C}(-)$ were calculated from published binding parameters [9].
C. However, inferences as to whether phospholipid-bound factor $\mathrm{Va}$ or unbound factor $\mathrm{Va}$ is the preferred substrate cannot be drawn.

To this end, we investigated the effect of phospholipids on the rate of proteolysis of the nonphospholipid-binding (factor Va heavy chain) and phospholipid-binding subunit (factor $\mathrm{Va}$ light chain), by activated protein $\mathrm{C}$. The time course of cleavage of ${ }^{125} \mathrm{I}$-labelled factor Va light chain and heavy chain by activated protein $\mathrm{C}$ in the absence and presence of phospholipids was monitored by measuring the radioactivity in respective regions of SDS-polyacrylamide gels corresponding to the position of factor $\mathrm{Va}$ heavy chain and factor $\mathrm{Va}$ light chain. Fig. 3A shows that the cleavage of factor Va light chain is stimulated by phospholipid, while the rate of conversion of the subunit that does not bind to phospholipid (factor $\mathrm{Va}$ heavy chain) is virtually unaffected by phospholipid (Fig. 3B). It is apparent that proteolysis by activated protein $\mathrm{C}$ is most effective when the substrate and activated protein $\mathrm{C}$ are bound to phospholipid. Moreover, it is interesting to note that in the absence of phospholipid the rate of degradation of factor Va light chain is higher than that of factor Va heavy chain.
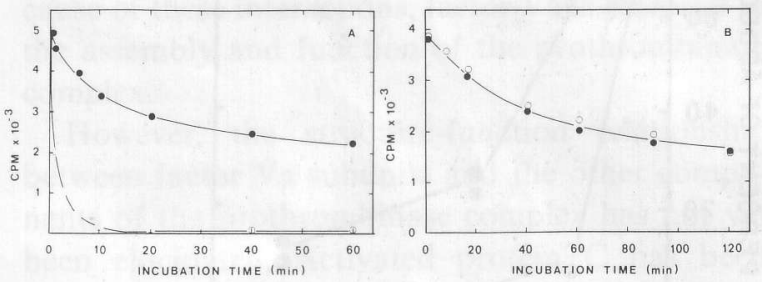

Fig. 3. Effect of phospholipid on the rate of proteolysis of factor Va heavy chain and factor $\mathrm{Va}$ light chain by activated protein C. Panel A, ${ }^{125} \mathrm{I}$-factor Va light chain $\left(1.8 \mu \mathrm{M}, 6 \cdot 10^{2}\right.$ cpm/nmol) in $20 \mathrm{mM}$ Tris, $100 \mathrm{mM} \mathrm{NaCl}, 3 \mathrm{mM} \mathrm{CaCl}{ }_{2}, \mathrm{pH}$ 7.5 was incubated with activated protein $C(45 \mathrm{nM})$ in the presence of $50 \mu \mathrm{M}$ phospholipid $(\mathrm{O}-\mathrm{O}$ ) or in the absence of phospholipid (- At intervals, aliquots were removed and electrophoresed on 10\% SDS-polyacrylamide gels. The gels were sliced in $2 \mathrm{~mm}$ sections and counted for radioactivity. Plotted is the radioactivity corresponding to ${ }^{125} \mathrm{I}$-factor $\mathrm{Va}$ light chain versus incubation time. Panel B, ${ }^{125} \mathrm{I}$-factor Va heavy chain $\left(0.2 \mu \mathrm{M}, 4 \cdot 10^{5} \mathrm{cpm} / \mathrm{nmol}\right)$ was incubated with activated protein $\mathrm{C}(0.1 \mu \mathrm{M})$ in the presence $(\mathrm{O}-\mathrm{O})$ or absence (-) of phospholipid. Further experimental details as in panel $\mathrm{A}$. 
Phospholipid-binding properties of proteolytic altered factor Va light chain

Binding of factor $\mathrm{Va}$ to phospholipid is essential to the rate of inactivation of factor $\mathrm{Va}$ by activated protein $\mathrm{C}$ as it is essential to the function of factor $\mathrm{Va}$ in prothrombin activation. Since factor Va binding to phospholipid is mediated through factor Va light chain [10], it is of interest to investigate whether the phospholipid-binding properties of factor Va light chain are altered after factor $\mathrm{Va}$ light chain is degraded by activated protein $\mathrm{C}$.

To this end, we performed a qualitative analysis of the phospholipid-binding properties of the factor Va light chain degradation products. Unfractionated degraded factor $\mathrm{Va}$ light chain was incubated with various amounts of large-volume vesicles. After centrifugation, the supernatants were analyzed by SDS-polyacrylamide gel electrophoresis. The amounts of $M_{\mathrm{r}} 51000$ and $M_{\mathrm{r}} 32000$ fragments were quantitated by densitometric scanning and plotted versus the phospholipid con-

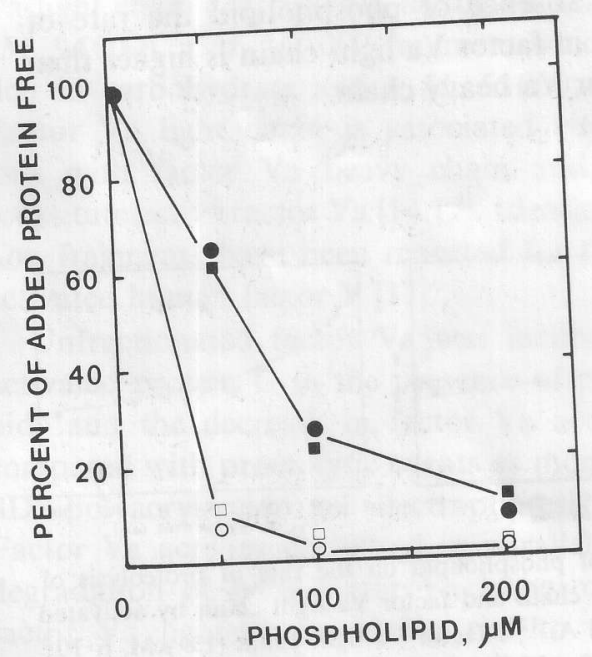

fig. 4. Phospholipid-binding properties of factor Va light chain degradation products. A mixture of the $M_{\mathrm{r}} 51000$ and $M_{\mathrm{r}}$ 32000 fragments $(2 \mu \mathrm{M})$ obtained after degradation of factor $\mathrm{Va}$ light chain by activated protein $\mathrm{C}$ was incubated with varying amounts of large volume vesicles in $50 \mathrm{mM}$ Tris, 100 $\mathrm{mM} \mathrm{NaCl}, \mathrm{pH} 7.5$ in the presence of $2 \mathrm{mM}$ EDTA (open symbols) or $5 \mathrm{mM} \mathrm{CaCl}_{2}$ (closed symbols). The amounts of unbound protein as a percentage of total added protein are plotted versus phospholipid concentration. $\mathrm{O}-\mathrm{O}$ and $\longrightarrow M_{\mathrm{r}} 32000 \mathrm{fragment} ; \square \longrightarrow \square$ and $\square, M_{\mathrm{r}}$ 51000 fragment. centration (Fig. 4). It was demonstrated that both fragments bound equally well to phospholipid. The binding of both fragments could be reduced by adding calcium to the reaction mixture. We previously reported a similar effect of $\mathrm{Ca}^{2+}$ for factor Va light chain-phospholipid interaction [10]. It can be questioned whether the $M_{\mathrm{r}} 32000 \mathrm{frag}$ ment arised from the $M_{\mathrm{r}} 51000$ fragment. However, both fragments are generated concomitant upon incubation of factor $\mathrm{Va}$ light chain with activated protein $\mathrm{C}$. Prolonged incubation did not alter the $M_{\mathrm{r}} 32000 / M_{\mathrm{r}} 51000$ fragments ratio.

Factor Va heavy chain-binding properties of proteolytic altered factor $\mathrm{Va}$ light chain

The divalent cation-mediated interaction between factor Va heavy chain and factor Va light chain is essential to the activity of factor Va $[14,15]$. Fig. 5 shows that factor Va activity, expressed as functional molar concentration [10], could be restored by incubation of equimolar amounts of factor Va light chain and factor Va heavy chain in the presence of $\mathrm{Mn}^{2+}$. Titration of a fixed amount of factor Va heavy chain with unfractionated factor $\mathrm{Va}$ light chain degradation products, i.e. and equimolar mixture of $M_{\mathrm{r}} 51000$ and $M_{\mathrm{r}} 32000$ fragments, in the presence of $\mathrm{Mn}^{2+}$, also resulted in the almost complete restoration of active factor $\mathrm{Va}$ (Fig. 5).

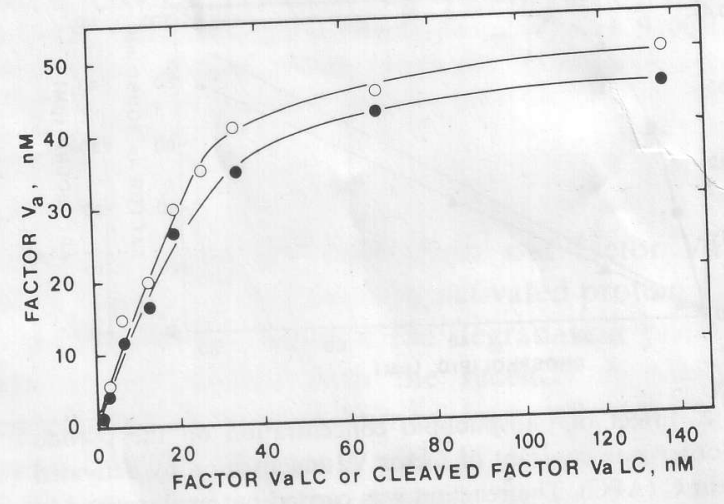

Fig. 5. Reconstitution of factor Va activity. Varying amounts of activated protein $\mathrm{C}$-cleaved factor $\mathrm{Va}$ light chain $(\mathrm{O}-\mathrm{O})$ or intact factor $\mathrm{Va}$ light chain (-) were incubated with factor $\mathrm{Va}$ heavy chain $(60 \mathrm{nM})$ in $50 \mathrm{mM}$ Tris, $100 \mathrm{mM} \mathrm{NaCl}$, $10 \mathrm{mM} \mathrm{MnCl}_{2}, \mathrm{pH} 7.5$ for $30 \mathrm{~min}$ at $37^{\circ} \mathrm{C}$, Samples were taken and assayed for factor $\mathrm{Va}$ activity as described in Materials and Methods. 
Factor Va activity could not be restored by titration of a fixed amount of factor Va light chain with unfractionated factor $V a$ heavy chain degradation products, i.e. and equimolar mixture of $M_{\mathrm{r}} 72000$ and $M_{\mathrm{r}} 24000$ fragments (data not shown). To ascertain that the cleaved factor $\mathrm{Va}$ heavy chain preparation is not contaminated with activated protein $\mathrm{C}$, we incubated $0.1 \mu \mathrm{M}$ of factor $\mathrm{Va}$ in $20 \mathrm{mM}$ Tris, $100 \mathrm{mM} \mathrm{NaCl}, 5 \mathrm{mM} \mathrm{CaCl}_{2}$, pH 7.5 with cleaved factor Va heavy chain (50 $\mathrm{nM}$ ) in the presence of $50 \mu \mathrm{M}$ phospholipid. Since no decrease in factor $\mathrm{Va}$ activity was observed, the presence of activated protein $\mathrm{C}$ could be ruled out.

Direct evidence that the factor $\mathrm{Va}$ light chain degradation products form a complex with factor $\mathrm{Va}$ heavy chain was obtained by size-exclusion HPLC. In the presence of EDTA, the elution times of factor $\mathrm{Va}$ heavy chain and $\mathrm{Va}$ light chain were $15.5 \mathrm{~min}$ and $19.5 \mathrm{~min}$, respectively (Fig. 6A). The $M_{\mathrm{r}} 32000$ and $M_{\mathrm{r}} 51000$ factor Va light chain degradation fragments eluted together (elution time was $23.3 \mathrm{~min}$ ) and close to the salt volume of the column, $24.0 \mathrm{~min}$ (Fig. 6C). The elution times of factor Va light chain and its fragments indicate a non-ideal size-exclusion retention mechanism. Ap-

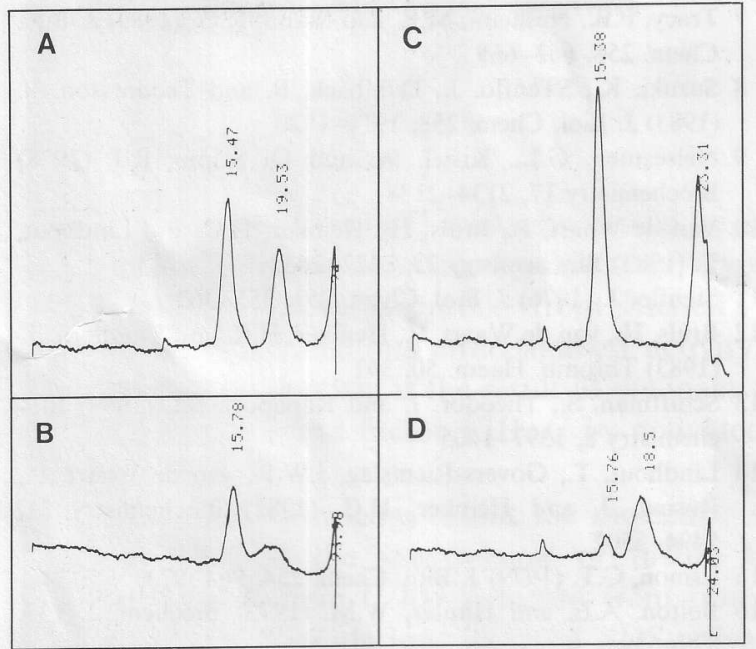

Fig. 6. Size-exclusion HPLC of factor Va subunits and restored factor $\mathrm{Va}$. Elution diagrams for factor $\mathrm{Va}$ light chain $(8 \mu \mathrm{g})$ and factor Va heavy chain $(10 \mu \mathrm{g})$ in the presence of $2 \mathrm{mM}$ EDTA (panel A) or $5 \mathrm{mM} \mathrm{MnCl}_{2}$ (panel C) and for activated protein C-cleaved factor Va light chain $(8 \mu \mathrm{g})$ and factor Va heavy chain $(10 \mu \mathrm{g})$ in the presence of $2 \mathrm{mM}$ EDTA (panel B) or 5 $\mathrm{mM} \mathrm{MnCl}_{2}$ (panel D). AUFS is 0.05 . parently, protein-support surface interaction dominates in the chromatogram.

In the presence of $\mathrm{Mn}^{2+}$, factor $\mathrm{Va}$ heavy chain and factor $\mathrm{Va}$ light chain form a complex with an elution time of $15.8 \mathrm{~min}$ (Fig. 6B). Factor Va activity eluted with the protein peak. The elution time of the complex $\left(M_{\mathrm{r}}\right.$ 174000) also showed non-ideal size-exclusion behaviour as was observed for factor Va light chain.

A mixture of equimolar amounts of factor $\mathrm{Va}$ heavy chain and cleaved factor Va light chain preincubated in the presence of $\mathrm{Mn}^{2+}$, eluted from the column as a major protein peak, which contained factor Va activity. The elution time is 18.5 min. The minor protein peak, elution time of 15.8 min, contained less then $1 \%$ of the total recovered factor $\mathrm{Va}$ activity (Fig. 6D).

\section{Discussion}

Single chain bovine factor $\mathrm{V}\left(M_{\mathrm{r}} 330000\right)$ is converted by thrombin into factor $\mathrm{Va}$, a two-subunit protein, i.e. a $M_{\mathrm{r}} 94000$ component associated via calcium ions with a $M_{\mathrm{r}} 80000$ component, and activation peptides with $M_{\mathrm{r}} 150000$ and $M_{\mathrm{r}} 65000$. As a consequence of this action of thrombin, the pro-cofactor acquires factor $\mathrm{Xa}$ and prothrombin binding sites, while the phospholipid-binding properties are only slightly changed $[10,17]$. Because of these interactions, factor $\mathrm{Va}$ is essential to the assembly and function of the prothrombinase complex.

However, the structure-function relationship between factor Va subunits and the other components of the prothrombinase complex has not yet been elucidated. Activated protein $\mathrm{C}$ has been used to probe the functions of the individual subunits $[3,7,8]$. These studies showed that factor Va activity decreased in parallel with the degradation of the $M_{\mathrm{r}} 94000$ component (factor $\mathrm{Va}$ heavy chain).

Information as to the consequences of the cleavage of factor $\mathrm{Va}$ light chain by activated protein $\mathrm{C}$ was not obtained, because the light chain of factor $\mathrm{Va}$ was partially [3] or not significantly [8] cleaved. That is, the cleavage of the heavy chain proceeded faster as compared to the cleavage of the light chain of factor Va. This is in contrast with our findings, where cleavage of the 
light chain proceeded at the same rate as the cleavage of the heavy chain (Fig. 1). It was noted by Walker et al. [3] that the differences in relative rates of proteolysis of the heavy and light chain was reduced in the presence of phospholipid. In view of the effect of the phospholipid concentration on the pseudo first-order rate constant of inactivation of factor $\mathrm{Va}$ and the phospholipid-binding properties of factor $\mathrm{Va}$ and activated protein C (Fig. 2), the notion arises that the differences in rates of light chain proteolysis as compared to the rate of proteolysis of the heavy chain might be due to the extent of the solution phase inactivation of factor $\mathrm{Va}$.

Direct evidence that inactivation of factor $\mathrm{Va}$ by activated protein $\mathrm{C}$ is solely the result of cleavage of the heavy chain was provided by the reconstitution experiments (Fig. 5). Whether or not cleavage of the heavy chain results in the loss of factor $\mathrm{Xa}$ and/or prothrombin binding to factor $\mathrm{Va}$, is an open question. Preliminary data showed that the $M_{\mathrm{r}} 72000$ fragment, derived from the heavy chain by activated protein $C$, interacts via calcium ions with phospholipid-bound factor Va light chain. Whether such a complex binds factor $\mathrm{Xa}$ and or prothrombin is the subject of further investigation.

As to the cleavage of the light chain, it is of interest to see that this proteolytic event does not effect the functional properties of factor Va (Fig. 5 ). We clearly demonstrated that the degradation products of the light chain bind to phospholipid (Fig. 4) and form a complex with the heavy chain (Fig. 6). It is apparent that both features are essential to the function of factor $\mathrm{Va}$ in the prothrombinase complex.

As to the stimulatory effect of phospholipid on the rate of inactivation of factor $\mathrm{Va}$, the two-subunit structure appears to be important. Although the rate of inactivation seems to depend on the amount of phospholipid-bound activated protein C (Fig. 2), binding of the substrate to phospholipid is required (Fig. 3). Proteolysis of factor Va heavy chain results in the inactivation of factor $\mathrm{Va}$. The factor Va light chain-mediated binding of the heavy chain to phospholipid is of paramount importance for a rapid cleavage by activated protein C. Therefore the conservation of the phospholipid and heavy chain binding properties of factor Va light chain after cleavage, is essential to the stimulatory effect of phospholipids on the inactivation of factor $\mathrm{Va}$ by activated protein $\mathrm{C}$.

\section{Acknowledgements}

We thank Barry Soute for his assistance in HPLC analysis and Dr. Margaret Rand for making linguistic improvements. The investigations were carried out with financial support given to one of us (P.v.d.W.) by the Netherlands Organization for the Advancement of Pure Research (ZWO).

\section{References}

1 Kisiel, W., Ericsson, L.H. and Davie, E.W. (1976) Biochemistry $15,4893-4900$

2 Kisiel, W., Canfield, W.M., Ericsson, L.H. and Davie, E.W. (1977) Biochemistry 16, 5842-5831

3 Walker, F.J., Sexton, P.W. and Esmon, C.T. (1979) Biochim. Biophys. Acta 571, 333-342

4 Seegers, W.H., Marlar, R.A. and Walz, D. (1978) Thromb. Res. 13, 233-243

5 Vehar, J. and Davie, E.W. (1980) Biochemistry 19, 401-410

6 Marlar, J., Kleiss, A.J. and Griffin, J.H. (1982) Blood 59, 1067-1072

7 Tracy, P.B., Nesheim, M.E. and Mann, K.G. (1983) J. Biol. Chem. 258, 662-669

8 Suzuki, K., STenflo, J., Dahlbäck, B. and Teodorsson, B. (1983) J. Biol. Chem. 258, 1914-1920

9 Nelsestuen, G.L., Kisiel, W. and Di Scipio, R.J. (1978) Biochemistry 17, 2134-2138

10 Van de Waart, P., Bruls, H., Hemker, H.C. and Lindhout, T. (1983) Biochemistry 22, 2427-2432

11 Stenflo, J. (1976) J. Biol. Chem. 251, 355-363

12 Bruls, H., van de Waart, P., Hemker, H.C. and Lindhout, T (1983) Thromb. Haem. 50, 342

13 Schiffman, S., Theodor, I. and Rapaport, S.I. (1969) Biochemistry 8, 1397-1405

14 Lindhout, T., Govers-Riemslag, J.W.P., van de Waart, P., Rosing, J. and Hemker, H.C. (1982) Biochemistry 21, 5494-5502

15 Esmon, C.T. (1979) J. Biol. Chem. 254, 964-973

16 Bolton, A.E. and Hunter, W.M. (1973) Biochem. J. 133, 529-539

17 Suzuki, K., Dahlbäck, B. and Stenflo, J. (1982) J. Biol. Chem. 257, 6556-6564 